\title{
Leader as Policy Device: The Hybridization of Head Teachers in Italy
}

\section{Roberto Serpieri - Emiliano Grimaldi}

Università degli Studi di Napoli Federico II - Department of Social Sciences (Italy)

doi: 10.7358/ecps-2015-011-serp

profrobertoserpieri@gmail.com

emilianogrimaldi@gmail.com

\section{IL LEADER COME DISPOSITIVO POLITICO: \\ L'IBRIDAZIONE DEI DIRIGENTI SCOLASTICI IN ITALIA}

\begin{abstract}
The aim of this article is to show how educational policies in Italy in the last 15 years have conceived headship as a "lever of change», producing a sort of «subjection" which implies a remarkable hybridization of the role. The ongoing pressures on policymaking by «noneducational" actors are depicted as a feature of the Italian policies on the restructuring of school governance and headship. The topics presented are based on researches carried out in recent years and focusing on the training, selection and evaluation of Italian head teachers. The article is structured as follows. Firstly, we present the theoretical framework based on the conceptual tools of discourse and governance. Secondly, we offer a brief outline on how head teachers were "formed" as educators before the 1997 Autonomy Reform. In the final section, some tensions that emerge during the discussions on headship are presented by analysing a particular set of "technologies" such as training, selection and evaluation that aim to "S-Objectivate» specific head teachers. The analysis will allow us to shed light on what we think of as an invisible and politically remarkable dilemma that is at stake here: "headship as a managerialist device to 'control' education policies».
\end{abstract}

Keywords: Control education policies; Italian head teachers: Leader; Managerialist device; Policy device. 


\section{INTRODUCTION}

In 2000, the Italian Minister of Education Luigi Berlinguer clearly explained the rationale underpinning the redesigning of the head teacher profile as a necessary complement and support to the 1997 School Autonomy Reform. The purpose was to reshape the professional role of the "old" primary and secondary school heads by diminishing their bureaucratic tasks and to search for a new professional profile. The aim of this article is to show how 15 years after the reform was launched, we are still facing a "war of discourses» (Serpieri, 2009). Such a war can be also interpreted as a result of the appropriation of the role of school headship by a number of actors, discourses and policies that are in a tension and struggle to prevail over one another. More specifically, our reasoning is that, similarly to what happened to education as a whole, the head teacher is no longer the «s-object» of attention and care of only politicians, education administrations, trade unions and professional associations. More and more, «non-educational» actors (Gunter, 2012) are entering the political-administrative arena of education with growing energy and vigour, attempting to subjugate to a sort of hidden "privatization" (see Ball, 2007 and 2012) (but sometimes this becomes an overt project) of education policies and their strategic and value choices. This becomes evident in the case of headship as well as for many other educational actors.

The points discussed in this article regard researches and publications carried out in recent years and focusing on the reform of the Italian education system, on its education policies and, more specifically, on the training, selection and evaluation of Italian head teachers. The article deals with the following points: firstly, the theoretical framework and methodology that have "shaped» the researches whose results are presented in the article. Secondly, a brief outline about the way head teachers used to be «formed» as educators before the 1997 Autonomy Reform. In the final sections, some tensions that emerge during the discussion on school heads are treated by analysing a particular set of «technologies» such as training, selection and evaluation that aim to $S$-Objectivate specific head teachers. The analysis will allow us to shed light on what we think of as an invisible and politically remarkable dilemma that is at stake here: the school headship as a managerialist device to "control» education policies.

\section{THEORETICAL FRAMEWORK}

In order to offer a "critical reading» of school headship policies in Italy, we recall here some conceptual tools we have used: firstly, we addressed the anal- 
ysis of the regimes of truth shaping and contributing to the governmentality of the field of education, using «discourses» as heuristic tools. Discourses, as Ball suggests, can be interpreted as ways of organizing «statements [...] slogans, recipes, magics and self-evidences» (2007, p. 3), "providing possibilities of political thought [...] rooted within material contexts and networks of social interaction" through which "policies accumulate credibility and legitimacy» (ibid., p. 2). Secondly, we tried to explore the new forms of educational governance - a "liberal governmentality construction of governing at a distance in which actors are invited to govern themselves rather than being directed, forced or coerced» (Newman \& Clarke, 2009, p. 18; Dean, 2010).

In terms of discourses, adopting the end of the Second World War as a starting point, we can identify a sort of historical global transition (Grimaldi \& Serpieri, 2012) from (a) a welfarist discourse putting the "hopes» of mass education in terms of social mobility and equity, and after 1968 the democratization of the forms of governance at the centre of attention; to (b) a neoliberalist discursive «reaction» that - since the 1980s, but a decade later in Italy - has denounced the "failures» of the welfarist educational project, asking for a step back by the State and the rethinking of education as a private good. Such a concept has been coupled with requests for privatization, a quasi-market and accountability policies that were external and extraneous to professional and bureaucratic logics. The late 1990s witnessed an attempt to tamper with the radical side of the neoliberal view by the bursting onto the scene of the so-called Third-way. The Third-way discursive constellation, starting from England and spreading to many western countries, aimed at mitigating the logics of efficiency and competitiveness with a recovery of the attention towards equity and citizenship. Managerialism acted as a transversal and unifying discourse between the two and originated, in particular, those forms of school "managerialization» ${ }^{1}$ that started with the introduction of the New Public Management (NPM) (Grimaldi \& Serpieri, 2013a). The picture of the discursive landscape in the field of education can be completed by outlining the dispersed traces of a democratic discourse. It is not easy to profile the democratic discourse as a unified framework (Olssen et al., 2014), in so far as it collects and comprises the multiplicity of those statements, subjects and practices that oppose the neomanagerialist, neoliberal and Third-way logics, pursuing an authentic recovery of welfarist values such as equity and citizenship, participation and collaboration as logics of regula-

1 The distinction between managerialism and managerialization (Clarke et al., 2000) implies that the former has a normative dimension, concerning beliefs, orientations and values while the latter indicates the spreading of managerial techniques and practices. 
tion and reaffirming trust as a central principle of the professional ecologies, together with an openness to dialogue with local communities and plural accountabilities.

In terms of governance, drawing from the analytic framework proposed by Newman, we could distinguish four models of governance (Newman, 2001, p. 33), deriving from the intersection of two heuristic dimensions: centralization/decentralization and stability/change: (1) the hierarchical model, «in which the State exerts direct control over policy development and implementation through bureaucratic hierarchies» (ibid.); (2) the rational goal model, characterized by managerial power and a dispersal of authority and agencies, but «despite this apparent devolution, this model of governance reflects a centralised approach with goals and targets cascading from the government $[\ldots]$ on the assumption that different organisations will behave as rational actors" (ibid., p. 34) fostering competition between each other; (3) the open system model, oriented towards «network forms of interaction and iterative processes of adaptation [...] based on the interdependence of actors on the resources of others to pursue their goals» (ibid., p. 35) and where government devolves its power and loosens ties of control; (4) the self-governance model, that focuses on «building sustainability by fostering relationships of interdependence and reciprocity» (ibid.) and on processes of empowerment by promoting participation in decision-making. Government devolves power «by developing the capacity of [professional or social] communities to solve their own problems" (ibid., p. 36).

The combination between discourses and frames of governance will allow us to analyse education systems as hybrid forms, assemblages subject to tensions and contradictions, that can be read and understood as processes rather than as structural fixities. Being inspired by the reading offered by Gunter (2012) on the policies for leadership promoted by New Labour in England during the 1990s, we have also devoted our attention to the implications of policies in terms of processes of «subjectivation» (Foucault, 1991), grasping in detail the managerialist tension towards "the transformation of expertise and the regulation of the activities of professionals» (Dean, 2010, p. 197). Such a move allowed us to further enrich the analytical framework and to make it more proximal to education policies which have attempted to enact head teachers as a «lever» for change in Italy. In the case of subjectivation processes, as for discourses and governance, it is pointless to strive for a structurally determined definition. Rather, it seems more productive to search for those devices that are not features of a model, but are the tesserae of the "actual» systems of educational governance. At this point, the device is meant as a heuristic one to analyse the interweave between knowledge, power and subjectivity - three dimensions that are in a perpetual movement of 
reciprocal intersection, sedimentation, fragmentation, stabilization and crisis (Deleuze, 1992). Following this line of thought, if headship were interpreted both as a device and «constrained» within devices, e.g. of evaluation, then it could not be understood through a univocal reading, once and for all. On the contrary, it would be a hybrid figure, always in becoming and subject to tensions and dilemmas produced by the intertwining of discourses, policies and actors.

\section{ITALIAN HEADSHIP: A HYBRID}

Analysing the Italian education system and applying Newman's (2001) conceptual framework to the dimensions of governance, curriculum, headship and evaluation (Serpieri, 2012; Grimaldi \& Serpieri, 2014), we noted how the Italian case represents a peculiar and hybrid form of «centralised decentralisation" (Karlsen, 2000), where the State still exerts a strong and pervasive influence on local authorities and schools through the definition of the national curriculum, the control of human and financial resources and, finally, the exercise of its general regulative powers. Here we wish to focus on some features of these complex processes of hybridization that are vital to understand our analysis on the "headship» issue. On the one hand, we wish to highlight the paradoxical coexistence of the permanence of a still hierarchical mechanism of control on the key actors and processes of education and the increasing establishment of devices of school and system performance evaluation based on collective agreement. We are, in fact, witnessing the adoption of typical NPM tools, such as management by objectives and performance-related pay, introduced through a set of national pilot policies on head teacher and teacher evaluation (Serpieri, 2012; Barzanò \& Grimaldi, 2013; Grimaldi \& Serpieri, 2013a). On the other hand, it is possible to observe the openness to forms of weak decentralization towards schools and local governments on issues such as pedagogical research and educational curriculum, territorial planning, the promotion of networks and partnerships, and fund raising. All these movements seem to prefigure a shift towards «heterarchical» governance (Jessop, 2002; Ball, 2009). However, the issue of school autonomy still remains at the centre of an intense and wide paradigmatic, discursive, ideological and political war. Nonetheless, despite the intrinsic difficulties of both the School Autonomy Reform and the related creation of a new headship, the general idea recognised by all is that the latter probably represents the most significant turning-point in the last decade. 
In a similar vein to what happened in other education systems, Autonomy has led headship to become part and device of a wider process of devolution towards the school level of responsibility for quality and performance «improvement». Thus, the head as manager has been identified as the lever of change to promote improvement and entrepreneurship, and this represents a central value that has inspired the attempts to reframe the external role of headship, in so far as head teachers have been identified as key actors in the new devolved local educational arenas designed through the reform. As we have observed elsewhere, first they are asked to establish relations and a positive climate with local governments and to be accountable to peripheral bureaucracies. Second, head teachers are required to explore and exploit partnerships and collaboration with institutional, cultural, social and economic groups existing in the school area. The new head teacher potentially becomes an entrepreneur with several imperatives. In order to maintain a sufficient number of pupils he/she has to make his/her school attractive for students, but mainly for their parents. The loss of students means fewer teachers and the risk of losing the autonomous status. To avoid these risks, the head teacher should seek to enrich the educational provision of the school by getting additional funding for extra-curricular activities. As a consequence, he/ she should dedicate a considerable amount of time to promoting external relations with local authorities and other public and private actors. In such a context, the development of entrepreneurial skills becomes a necessity, while competition and a customer-oriented ethos turn out to be new hidden values (Whitty, 2002). This could also be an initial step of a "privatisation" process (Ball, 2007) within the Italian school system. At the same time, the condition of decentralisation combined with external accountabilities not only implies a neoliberal discursive featuring of heads, but also a Third-way one. Spaces of potential (Gronn, 2010) for leadership are also opened up by the encouragement of network practicing, sustained by collaboration and partnership between schools and other organisational agencies (public, private and non-profit ones). So far, these have been scarcely explored interstices where a democratic discourse starts to exert a new moral climate, whereas aims of social justice and democratic citizenship should and could be pursued, whilst bearing in mind the increase of intercultural educational needs in Italy.

Reading about the formation of the new headship through the lenses of Newman's (2001) governance models and discourses (Ball, 1994), has allowed us to show how such an actor/player/subject stands out as the most hybridised figure within the magmatic processes of change enacted both by the School Autonomy Reform and the neo-liberal and Third-way "winds of change». In the next section, on the devices of «formation» and evaluation of 
headship in Italy, we will try to highlight what form this managerialist imaginary of a global process of policy convergence is taking on (Rizvi, 2006) in our country and the role the «invasion» of the education/public field by «non educational actors» (Gunter, 2012) coming from the economic/private sector is playing in the process.

\section{THE INVASION OF THE «NEW BARBARIANS»}

In introducing this work, we quoted Mr. Berlinguer, a former Minister of Education in a past "Centre-Left» government, who could benefit from a considerable continuity in government (1996-2000) to launch the School Autonomy Reform, after years of impasse in Italian education policy (Grimaldi \& Serpieri, 2012). As Serpieri has described in more detail elsewhere (Serpieri, 2012), Berlinguer surely had the intention to go beyond a bureaucratic understanding of headship, overcoming the limits of such a role as established by the welfarist bureau-professional compromise. At the same time, he seemed to be inclined to boost the professional part, mainly interpreted as the enactment of a renewed educational leadership that (re)valued teachers work, a democratic attention to local educational communities and, in general to, the territory. The democratic statements were mitigated, in Berlinguer's rhetoric, through the managerialist emphasis on entrepreneurship and resource management. In such a hybrid, we can recognize the ascendance of the Third-way.

If a leftist minister had already imagined such a hybrid figure, the push towards a clear entrepreneurial and managerial turn of the head teacher has been exerted since the beginning of this season of reforms by the most prominent champions of the managerialist discourse, such as some professional associations, the centre-right parties, entrepreneur representatives, and others, together with some foundations and philanthropic organisations (see Ball, 2007 and 2012 on the use of this concept) belonging to this same discursive domain. A declaration in a yearly working paper issued by one of these foundations which has progressively acquired a relevant influence in education policy can be taken as an example.

The first problematic aspect lies in the fact that the head teacher's professional profile has been tailored on the model of bureaucracy without looking at the managerial model (power and responsibility). [...] and, in any case, s/he does not have any power over the teaching and non-teaching staff since s/he does not evaluate, recruit, select and sanction or reward. Nevertheless, s/he is formally responsible for their results. (Treellle, 2006, p. 50) 
At this point, the explicit request is to profile the professional character of the head teacher as a manager. In the next few years such a request will become increasingly clear and evident, although «wrapped» with the rhetorical reference to a function of distributed or shared leadership that has been re-discovered, in Italy as well, as a sort of Trojan horse (we shall come back to this later) for the invasion of the "new barbarians» of management discourse for the conquest of the public education field. The bursting onto the scene of the foundations represents only the "last act» of an increasing broad and pervasive «invasion» of actors coming from the private and economic fields, who are determined and facilitated by the spreading of various forms of «privatization" (Ball, 2007 and 2012) of education policies. The stepping into the education arena of these new policy actors enacts the ongoing formation of a constellation of heterarchical networks of social relations involving philanthropists, businesses and charity organisations, banks, politicians, civil servants, national and international institutional agencies, experts and consultants, universities and academics, pioneer schools, head teachers and teachers, and trade unions. Since 2008 these new policy entrepreneurs have gained increasing importance in education policymaking and this coincides with an intense activity of cognition, calculation, experimentation and evaluation (Barzanò \& Grimaldi, 2013), and a flourishing of reports, conferences, publications, newspaper articles, press releases and public debates. A two-way flow of actors and ideas between state and (education) services and the private sector initiates the heavily influenced policy thinking about education. Philanthropic actors and their experts become the key promoters, relays and legitimizers of the organising watchwords of the new discourse of education reform (Grimaldi \& Serpieri, 2013b).

This a phenomenon has taken on various forms and in the next sections of this work we will try to highlight how these new private, economic and philanthropic actors have played a decisive role in the development of the policy trajectory that is slowly leading towards the establishment of a national evaluation system in the field of education and, more in detail, the ongoing constitution of two material devices of "policy governmentality" (Bailey, 2013) that were intended to reshape both the "formation» of the head teacher, and his accountability. It was Minister Berlinguer himself who suddenly opened to the private and «non-educational» actors (Gunter, 2012) and to those coming from the economic field, upsetting the previous scenario where pedagogic-humanistic actors were the most influential in inspiring educational policymaking in Italy. As Serpieri has shown in a recent study on the complex and troubled training process that was designed in 1999/2000 to trans-form the «old» head teachers into «new» ones, the Ministry of Education decided to outsource the training to 18 training agencies, belonging 
both to the private (e.g. companies) and the public sector (e.g. universities), often in partnership (Serpieri, 2009 and 2012). Exploring what we could call the first battle of the war of discourses developing around the design of the new head teacher, it was possible to identify a provisional but clear victory, in an open market competition, of the champions of management discourse, which succeeded both in obtaining the majority of the resources distributed by the Ministry and in promoting a managerial and entrepreneurial view of the new head teacher profile.

Thus, we could speak of a complex and long-standing process, showing the dynamics of the involvement of private actors within the selection and training of the Italian head teachers in the era of School Autonomy. The history of head teacher evaluation is even more emblematic in this respect and makes the ongoing processes of hybridization generated by the struggle between different and conflicting discourses visible. For more than 10 years the attempts to introduce new managerialist devices of accountability (performance management, management by objectives) along with the legal-financial control typical of the bureaucratic setting have failed. To be precise, the history of headship evaluation in Italy started in 1999, with Decree 286/1999, and the first trial started simultaneously in 1999 during the training and selection process we mentioned above. This was a hesitant and uncertain trial whose evaluation technology was mainly based on selfevaluation and the definition of the objectives to be pursued by the head teachers themselves. It was Decree 165/2001 that introduced, at least formally, the management by objectives logic and the principle of contractualism (Yeatman, 1994, p. 110), giving proof of the decrease of trust in schools and their professional groups, and hence in the forms of self-evaluation. Different trials followed and different models were tested. Since the trails failed, it is possible to observe the progressive and paradoxical belief that schools have to be entrusted to the therapeutic care of "heroic» leadership, along with the general idea that we have called elsewhere the «diagnostic turn» (Grimaldi \& Serpieri, 2013a). Heroic leadership is the magic that can guarantee the effective accomplishment of the improvement plans, and measurement becomes more and more urgent and pressing. Moreover, according to different political cycles, three different editions of another project (SIVADIS) commenced in 2001, 2003 and 2005. In 2008 another project (GPSS) started, a technology where an important role is played by economic logic and actors. The latest act of this programme, although still provisional, is the 2012 VALES, a still ongoing experiment that follows an intense season of education policymaking where the focus seemed to shift from the evaluation of the head teacher to that of schools and teachers. As in the case of selection and training, we have used a matrix with two dimen- 
sions (public/private and education/economy) to outline the scenario of head teacher evaluation policies, reconstructing a map of the relationships between institutional and organisational actors, and evaluation devices and artefacts (a more detailed account is offered in Serpieri, 2012, and Grimaldi \& Serpieri, 2013b).

Following a diachronic logic, it is possible to observe how from the first SIVADIS experiment to the GPSS, the Ministry enrolled a group of experts coming from public universities, but linked to the private consultancy sector. Shifting from one model to another, however, the economic aspect becomes more and more pervasive. This is clearly recognisable in the key role played by another in-house agency of the Ministry, the INVALSI which has been directed by a chief executive of the Bank of Italy since 2008, and the growing influence exerted by the Ministry of the Economy on the key decisions of education policies under the last centre-right government. Such a shift is not only determined by the financial crisis and the austerity imperatives, but also by the increasing importance of a vision of education functional to competitiveness in the global scenario. This is quite evident in the celebration of the hopes and gambles of the human capital theory, as described in a book written by two chief executives of the Bank of Italy who have directed the INVALSI from 2008 to the present day (Cipollone \& Sestito, 2010). The decreasing resort to pedagogics and sociologists of education in contrast to the increasing resort to experts from the economy of education and management studies of the Ministry also confirms the greater influence of the economic field.

The peak of the interference of the private and economic field in education policymaking corresponds, however, to a shift of the policy focus from head teacher evaluation to school and teacher evaluation when the Ministry of Education launched two umpteenth pilot policies. The design of the pilot policies was somehow delegated to three philanthropic foundations, clearly linked to the entrepreneurial and financial world, together with some champions of the fashioned meritocratic turn. We do not have the space here to go into detail on the two pilot policies (for a detailed analysis, see Barzanò \& Grimaldi, 2013, and Grimaldi \& Serpieri, 2013b). However, we would like to highlight how the two policies have followed two different logics, reflecting the diverse discursive and ideological positions of the three foundations that inspired them.

On the one hand, the Agnelli Foundation put at the centre of the pilot Evaluating School Quality (VSQ) project the «magic formula» of added value to measure the contribution of the school in producing student results. The economists of education and the INVALSI heavily supported such a concept/technique (a sort of magic, given the inscrutability of its mathematical 
algorithm). On the other hand, the School Foundation of the San Paolo Society and Treellle promoted a merit-based teacher evaluation through the introduction of the reputational methodology. Here, too, the head teacher is not directly evaluated, but - on the contrary - becomes an evaluator, being the coordinator of an internal committee whose task is to evaluate and reward the best teachers.

So headship evaluation, and the devices for its enactment, continue to be hybridized and in tension under the pressures of different discourses and actors. In such a struggle, the management discourse and its voices are more and more pervasive and aggressive in the Italian education field. In recent months, in the middle of a period of political instability following the change from a government of technicians to a "great political coalition" government, what seemed to be the unexpected outcome was a sort of evaluation turning point which gave rise to the establishment, at least in the legislation, of a National Evaluation System, whose centre is undoubtedly the INVALSI (led by the Bank of Italy) with its contested system of national tests. It also gave new impetus to a new pilot program, VALES (Evaluating and Developing School), that integrates the measurement of the school added value with the evaluation of the head teacher.

\section{CONCLUSIONS}

In this article we have tried to show how, after the 1997 School Autonomy Reform, the role of the head teacher in Italy has been re-designed in the attempt to go beyond its dominant bureaucratic features (Cavalli, 2012), without forgetting the professional ones of primus inter pares (that were present, although enacted patchly). Whereas many hopes of the autonomy turn were restrained by the complex and mazy tangle of interests, discourses, alliances and path-dependencies, many have seen in the redesign of headship the «lever» of change, often depicted according to the myth of the heroic of «transformational» leader (Leithwood, 1992). Headship itself has been viewed as a privileged "dispositif» (Foucault, 1975) to steer the new and contradictory governance of the autonomous school, in a wider scenario of "centralized decentralization" (Karlsen, 2000). As already happened in England (Gunter, 2012) or in the restructuring of other education systems (Derouet \& Dutercq, 1997; Blackmore \& Sachs, 2007), a vast array of discourses and actors have tried to impose visions directly or indirectly stemming from the neoliberal imaginary (and its Third-way variant), importing a-critically the travelling policies centred on the role of leadership as a push 
for improvement. As such, educational leadership has become a powerful neoliberal government dispositif (Bailey, 2013) but, at same time, its sedimentation has developed through dis-continuities, complexities and fractures. The result is that the Italian head teacher is still a hybrid. Hybrid is the design of his/her professional profile, where the widening of its tasks and responsibility, as many head teachers and other actors complain, has not been accompanied by a real devolution of powers from the centre and by the creation of the conditions for an actual autonomy. Hybrid is also the practice of headship in Italy, as shown by the researches by Fischer and colleagues (Fischer \& Masuelli, 1998; Fischer et al., 2002; Cavalli \& Fischer, 2012). A different and complex typology of headship enactments has emerged from these studies, also in relation to the generational change and the feminization of the profession.

Thus, on the one hand, most of the neo-management demands have remained unmet, as a consequence of the substantive failure of the selection, recruitment, training and evaluation dispositifs that have been substituited since 2000. Whereas, head teachers and their unions and professional associations claim for career and pay increases, complaining about the differences from other public managers (see Serpieri, 2012). On the other hand, it is possible to observe many forms of "punctual» resistance: (a) in the schools through the enactement of innovative professional cultures, especially in some disadvantaged contexts (Grimaldi, Romano, \& Serpieri, 2011; Serpieri \& Grimaldi, 2013 and 2014); (b) in the institutional and political-unionist arenas, where diverse voices still contrast the dismantling of the democratic architecture of the school communities. A proof of the effectiveness of those forms of resistance are the ongoing failures in changing the school internal governance (and the various councils) and the harsh struggles between political parties, unions and professional associations, originating from any attempt to reform it.

In concluding this article, we will try to summarize the hybrid character of the Italian head teacher outlining the two main points of its role. On the one hand, to outline the management demands, we will use as an exemplification, the contents of a recent publication issued by two of the foundations we discussed about in the previous sections, Treellle and the Fondazione per la Scuola della Compagnia di San Paolo (School Foundation of the San Paolo Society). The publication collected the proceedings of a seminar on headship (Treellle \& Fondazione per la Scuola, 2013), where the head teacher is framed, consistently with the management mantra, as a dispositif of steering and control that: distributes leadership through the constitution of a dedicated middle management; manages the cycle of human resources in the school, and above all the teachers, evaluating and rewarding the most «deserving»; 
is a monocratic decisional body, whereas the teachers' councils should have only an advisory role; guarantees the achievement of the learning aims, as set and evaluated by the centre; promotes the school improvement, according to government policies and guidelines provided by the Ministry of Education. In this profiling one can recognize the echoes of managerial ideas and policies imported or borrowed from other countries, all centred on an imaginary of leadership labelled from time to time as heroic, distributed or shared.

Such an overburdening hides a process of subjugation of / domination on the teaching profession enacted through the dispositif of headship/leadership (Gronn, 2003; Thomson, 2009), limiting the internal distribution of leadership to a mere delegation of power to trusted collaborators. In such a situation it is quite obvious that leadership, as a "third competence» that should complement the bureaucratic and managerial ones, is reduced to a narrow space of influence and consensus manipulation, as the critique of transformational and distributed leadership theories has clearly shown (Serpieri, Grimaldi, \& Spanò, 2009). Influence and manipulation are presented as the "real and proper function of the 'leader' that is to coordinate and motivate organizational actors to achieve common objectives» (Treellle $\&$ Fondazione per la Scuola, 2013, p. 20). At the same time leadership is understood as the expression of "relational and managerial competences» (ibid., p. 121), fulfilling a sort of ideo-logic short circuit, a proper truism, where the manager is such if he is leader and vice versa.

On the other hand, a radically different perspective is promoted by a democratic discourse, that critically engages with the ambiguities and contradictions of headship as a dispositif of "control» (see Hall, 2013). This is quite evident in the literature on «democratic» (Woods, 2005) leadership, where schools are conceived as local professional communities and non hierarchical organizations, whose aim is to include and compensate inequalities rather than pursuing objectives of effectiveness and efficiency. Here schools are asked to develop capabilities and aspirations of democratic citizenship and critical thinking in their students, professional and local communities. In this respect, breaking down the implicit automatism the managerial discourse enacts in proposing the equation distributed = democratic leadership, a democratic discourse (Olssen et al., 2004) reframes leadership as a process rooted in "a context of networks of practice» (Serpieri, 2008), as something that is put in practice through a configuration «a wholeness [that] consisting of a series of 'role-sets'» (Gronn, 2010, p. 425). Such a view of a democratic leadership as a process has "potentials» (Gronn, 2009) that express itself not only in the institutional structure (i.e. through the internal governance), but also in terms of resistance against the neoliberal and neo-managerial «subjectivation» (Ball, 2013) fostered by the new evaluation dispositifs. Such a 
resistance takes also the form of the attempt to revitalize forms of democratic participation (Grimaldi, 2010), both within school councils and school networks, breaking the competitive logic of partnership.

We hope we have shown with clarity how the future of headship and head teachers in Italy is still uncertain and will depend upon the outcome of harsh struggles and frictions between discourses, the cycles of politics and the increasing capacity of NPM and managerialism to act as transversal discourses. Headship, in this respect, is and will be more and more a dilemmatic dispositif of power and government. The specific question is here: a dispositif for a school subjugated to the economy or a school oriented towards the common good (Hardt \& Negri, 2009)?

\section{REFERENCES}

Bailey, P. L. J. (2013). The policy dispositif: Historical formation and method. Journal of Education Policy, 28(6), 807-827.

Ball, S. J. (1994). Education reform: A critical and post-structural approach. Buckingham: Open University Press.

Ball, S. J. (2007). Education PLC. London: Routledge.

Ball, S. J. (2009). Beyond networks? A brief response to "Which networks matter in education governance?». Political Studies, 57, 688-691.

Ball, S. J. (2012). Global education inc. New policy networks and the neo-liberal imaginary. London: Routledge.

Ball, S. J. (2013). Foucault, power and education. New York: Routledge.

Barzanò, G., \& Grimaldi, E. (2013). Discourses of merit. The hot potato of teacher evaluation in Italy. Journal of Education Policy, 28(6), 767-791.

Blackmore, J., \& Sachs, J. (2007). Performing and reforming leaders. Gender, educational restructuring, and organizational change. New York: Suny.

Cavalli, A., \& Fischer, L. (a cura di). (2012). Dirigere la scuola oggi. Bologna: il Mulino.

Cipollone, P., \& Sestito, P. (2010). Il capitale umano. Bologna: il Mulino.

Clarke, J., Gewirtz, S., \& McLaughlin, E. (Eds.). (2000). New managerialism, new welfare? London: Sage.

Dean, M. (2010). Governmentality. Power and rule in modern society (2nd ed.). London: Sage.

Deleuze, G. (1992). What is a dispositif? In T. J. Armstrong (Ed.), Michel Foucault: philosopher (pp. 159-167). New York: Routledge. 
Derouet, J. L., \& Dutercq, Y. (1997). L'établissement scolaire, autonomie locale et service public. Issy-les-Moulineaux: ESF.

Fischer, L., Fischer, M. G., \& Masuelli, M. (2002). I dirigenti nella scuola dell'autonomia. Bologna: il Mulino.

Fischer, L., \& Masuelli, M. (1998). I dirigenti e l'autonomia delle scuole. Milano: Franco Angeli.

Foucault, M. (1975). Surveiller et punir. Naissance de la prison (trad. it., Sorvegliare e punire. Nascita della prigione. Torino: Einaudi, 2005).

Foucault, M. (1991). Governmentality. In G. Burchell, C. Gordon, \& P. Miller (Eds.), The Foucault effect: Studies in governmentality (pp. 73-86). London: Harvester Wheatsheaf.

Grimaldi, E. (2010). Discorsi e pratiche di governance della scuola. Milano: Franco Angeli.

Grimaldi, E., Romano, T., \& Serpieri, R. (2011). I discorsi della dispersione. Una politica di partenariato. Napoli: Liguori.

Grimaldi, E., \& Serpieri, R. (2012). The transformation of the education state in Italy: A critical policy historiography from 1944 to 2011. Italian Journal of Sociology of Education, 4(1), 146-180.

Grimaldi, E., \& Serpieri, R. (2013a). Jigsawing education evaluation. Pieces from the Italian new public management puzzle. Journal of Educational Administration and History, 45(4), 306-335.

Grimaldi, E., \& Serpieri, R. (2013b). Privatising education policy-making in Italy: New governance and the reculturing of a welfarist education state. Education Inquiry, 4(3), 443-472.

Grimaldi, E., \& Serpieri, R. (2014). Italian education beyond hierarchy: Governance, evaluation and headship. Educational Management Administration and Leadership, 42(4), Suppl., 119-138.

Gronn, P. (2003). The new work of educational leaders. London: Sage.

Gronn, P. (2009). Ibryd leadership. In K. Leithwood, B. Mascall, \& T. Strass (Eds.), Distributed leadership according to the evidence. New York: Routledge.

Gronn, P. (2010). Leadership: Its genealogy, configuration and trajectory. Journal of Educational Administration and History, 42(4), 405-435.

Gunter, H. (2012). Leadership and the reform of education. Bristol: Policy.

Hall, D. (2013). Drawing a veil over managerialism: Leadership and the discursive disguise of the New Public Management. Journal of Educational Administration and History, 45(3), 267-282.

Hardt, M., \& Negri, A. (2009). Commowealth (trad. it., Comune: oltre il privato e il pubblico. Milano: Rizzoli, 2010).

Karlsen, G. E. (2000). Decentralized centralism: Framework for a better understanding of governance in the field of education. Journal of Education Policy, $15(5), 525-538$. 
Jessop, B. (2002). The future of the capitalist state. Bristol: Polity.

Leithwood, K. (1992). The move toward transformational leadership. Educational Leadership, 49(5), 8-12.

Newman, J. (2001). Modernising governance. London: Sage.

Newman, J., \& Clarke, J. (2009). Publics, politics and power: Remaking the public in public services. London: Sage.

Olssen M., Codd, J., \& O’Neill, A. M. (2004). Education policy: Globalization, citizenship and democracy. London: Sage.

Rizvi, F. (2006). Imagination and the globalisation of educational policy research. Globalisation, Societies and Education, 4(2), 193-205.

Serpieri, R. (2008). Senza leadership: un discorso democratico per la scuola. Discorsi e contesti della leadership educativa. Milano: Franco Angeli.

Serpieri, R. (2009). A «war» of discourses. The formation of educational headship in Italy. Italian Journal of Sociology of Education, 1(1), 121-142.

Serpieri, R. (2012). Senza leadership: la costruzione del dirigente scolastico. Dirigenti e autonomia nella scuola italiana. Milano: Franco Angeli.

Serpieri, R., \& Grimaldi, E. (2013). Che razza di scuola. Praticare l'educazione interculturale. Milano: Franco Angeli.

Serpieri, R., \& Grimaldi, E. (2014). Inclusione e scuola multiculturale. Pratiche e contesti a Napoli. Milano: Franco Angeli.

Serpieri, R., Grimaldi, E., \& Spanò, E. (2009). Discourses of distribution: Anchoring educational leadership to practice. Italian Journal of Sociology of Education, 3(3), 210-224.

Thomson, P. (2009). School leadership. Heads on the block? London: Routledge.

Treellle (2006). Per una scuola autonoma e responsabile. Analisi, confronti e proposte. Quaderno, 5.

Treellle \& Fondazione per la Scuola (2013). I dirigenti scolastici: funzioni, reclutamento, valutazione in Italia e in Europa. Seminario, 13 Aprile.

Whitty, G. (2002). Making sense of education policy. London: Sage.

Woods, P. A. (2005). Democratic leadership in education. London: Paul Chapman.

Yeatman, A.(1994). Postmodern revisionings of the political. New York: Routledge.

\section{Riassunto}

Lo scopo di quest'articolo è quello di mostrare come le politiche educative in Italia negli ultimi 15 anni hanno concepito la dirigenza scolastica come una leva per il cambiamento, producendo una «soggettivazione» che ha implicato una considerevole ibridazione del ruolo. Un tratto delle politiche di ristrutturazione della "governance" scolastica e della 
dirigenza è rappresentato dalle sempre maggiori pressioni di attori "non-educativi» sul "policy-making". Gli argomenti presentati si basano su ricerche pubblicate negli anni recenti e focalizzate sulla formazione, al selezione e la valutazione dei dirigenti. L'articolo è strutturato come segue: innazitutto si presenta il quadro concettuale basato sugli strumenti "discorsi» e "governance»; segue un resoconto della formazione dei dirigenti dopo la Riforma della Scuola dell'Autonomia; infine si presenta e discute la soggettivazione dei dirigenti attraverso il dispiegamento di "tecnologie» come quelle di formazione e valutazione. La nostra analisi getta luce sulla possibilità di riflettere su un rilevante problema politico: quello di intendere la dirigenza come un "dispositivo managerialista per 'controllare' le politiche scolastiche».

Parole chiave: Control education policies; Italian head teachers: Leader; Managerialist dispositive; Policy dispositif. 